\title{
POST-FIRE MANAGEMENT OF MEDITERRANEAN FORESTS: CARBON STORAGE IN REGENERATED AREAS IN EASTERN IBERIAN PENINSULA
}

\author{
D. MOYA*, R. ALFARO-SÁNCHEZ, F. LÓPEZ-SERRANO, T. DADI, \\ E. HERNÁNDEZ-TECLES, P. FERRANDIS, J. DE LAS HERAS
}

Escuela Técnica Superior de Ingenieros Agrónomos y de Montes. Universidad de Castilla-La Mancha. Campus Universitario s/n. 02071 Albacete (Spain).

\begin{abstract}
Management of burnt forests is a topic that should include monitoring of burnt areas immediately after burning, in order to implement emergency actions that ensure conditions for ecosystem recovery. However, if excessive regeneration is observed, early silvicultural treatments have to be implemented to assist the natural recovery of the ecosystem. This paper discusses the effects of silvicultural management in two burnt areas naturally regenerated. One of the study areas was located in southern Albacete province, covered of Aleppo pine (Pinus halepensis Mill.) stands that were burnt in summer 1994. The other area was located in eastern Cuenca province, showing Holm oak (Quercus ilex L. ssp. ballota (Desf.) Samp) stands burnt twice in summer 1993 and 2001. The objective of the current study was to monitor the biomass recovery and carbon stock in two different ways: direct field sampling and calculation of stocks by using available published datasets. Direct sampling showed that in 2010 (nine years after fire), lower amounts of carbon were stored in the young Holm oak standards which were not totally recovered from previous thinning, carried out two years ago. In 2010, sixteen years after the fire and nine after thinning, high intensity thinning contributed to improve the total amount of carbon stock in tree biomass in the Aleppo pine stands. In addition, values for unthinned areas were similar to those obtained from the Third Spanish National Forest Inventory. In this study we highlight the interest of implementing a classical tool of silvicultural management in the adaptive forest management of regenerating areas. We propose to consider the inclusion of young regenerated stands in carbon stocks, at least at province and regional level.
\end{abstract}

Manejo post incendio de bosques mediterráneos: almacenamiento de carbono en áreas regeneradas en el este de la Península Ibérica

RESUMEN. El manejo de las masas forestales incendiadas debe incluir un seguimiento desde el primer momento tras el incendio, optimizando la imple- 
mentación de medidas urgentes que aseguren unas condiciones mínimas para la regeneración natural del ecosistema. Sin embargo, ante una regeneración excesiva, se deben plantear tratamientos selvícolas tempranos como apoyo a la recuperación del ecosistema. En este trabajo se discuten los efectos del clareo temprano en dos zonas incendiadas y regeneradas de manera natural situadas en el este peninsular, una en el sur de Albacete con masas de pino carrasco (Pinus halepensis Mill.) quemadas en el verano de 1994, y otra al este de Cuenca, con masas de carrasca (Quercus ilex L. ssp. ballota (Desf.) Samp), quemadas repetidamente en los veranos de 1993 y 2001. El objetivo de este estudio es monitorizar la recuperación de biomasa y el almacenamiento de carbono de estas masas naturales, mediante muestreo directo en campo y por cálculo de existencias obtenidas de bases de datos públicas. El método directo mostró que la disminución del carbono almacenado en las especies estudiadas fue debido a la reducción inicial del número de árboles, que en los encinares no se había recuperado totalmente en 2010 (dos años después del tratamiento y nueve tras incendio). En 2010, dieciséis años después del incendio y seis tras el tratamiento silvícola, obtuvimos que en el pinar, los clareos de alta intensidad mejoraron la capacidad de la masa arbórea para almacenar carbono. Además, los valores de carbono almacenado en la biomasa arbórea en áreas no tratadas eran comparables a los valores del Tercer Inventario Forestal Nacional. Por tanto, se pone de relieve el interés del uso de la implementación de esta herramienta de manejo selvícola en un manejo forestal adaptativo y se propone la inclusión de masas jóvenes en regeneración dentro de los cálculos de almacenaje de carbono, al menos a niveles provinciales y regionales.

Key words: post-fire restoration, adaptive management, resilience, carbon pool, wildfires.

Palabras clave: restauración tras incendio, manejo adaptativo, resiliencia, almacén de carbono, incendio forestal.

Received 21 December 2013 Accepted 2 February 2014

*Corresponding author: Escuela Técnica Superior de Ingenieros Agrónomos y de Montes. Universidad de Castilla-La Mancha. Campus Universitario s/n. 02071 Albacete (Spain). E-mail: Daniel.Moya@uclm.es

\section{Introduction}

The forests of the Iberian Peninsula are diverse in terms of climate, vegetation and historical management. Fire regime in the Iberian forest areas has been related to each climate and forest type (Moreno and Chuvieco, 2013). In particular, differences among fire regimes are mainly related to climate type, whether Oceanic or Mediterranean, and to plant communities, but also to adaptions to fire-prone 
habitats attained by these communities (Vega et al., 2013). However, land use and landscape changes (LULC), fire policy and climate change scenarios contributed to alterations in the historical fire regimes (Pausas, 2006). Increased fuel load in unmanaged Mediterranean forests increased size and frequency of wildfires than historically (Pausas and Paula, 2012; Pausas and Fernández-Muñoz, 2012).

Depending on climate characteristics and fuel characteristics, the size and severity of wildfire may vary, resulting in different levels of tree mortality and landscape change (Moya et al., 2013). Factors such as historical management, pest attacks and activity of fungal pathogens create a mosaic of conditions across the landscape and will increase (or mitigate) the negative effects of fires (Mazza, 2007). The effects of fire in different forest types have been well documented in the scientific literature; however, uncertainty remains about the outcomes of different management options after the fire and scarce about adaptive management (Vayreda, 2013). After large forest fires, the optimal management will depend on fire effects, ecosystem response and management goals (Martinez-Sánchez et al., 1999; González-Ochoa and De las Heras, 2002; Castro et al., 2011; Lombardero and Ayres, 2011), being no action the main option (Mazza, 2007). Depending on the ecosystem response, the general lines of management are no action (optimal recovery), active restoration (null or inadequate regeneration) and assistance to regeneration implementing adapted silvicultural treatments (excessive tree density or alien invasion).

The evergreen oak and resprouter holm oak (Quercus ilex L. ssp. ballota (Desf.) Samp) together with the coniferous and obligate seeder Aleppo pine (Pinus halepensis Mill.) are two of the most important tree species in the western Mediterranean Basin, mainly in low and dry areas (Terradas, 1999; Quezel, 2000). Early silvicultural treatments after fire, such as thinning and pruning, improved nutrient availability in both species (López-Serrano et al., 2006) and promoted growth and cone production in Aleppo pine stands (González-Ochoa and De las Heras, 2002; Moya et al., 2008). Furthermore, silvicultural treatments also influenced forest productivity and the carbon sink (Bravo, 2007; De las Heras et al., 2013b). By using National Forest Inventories, significant differences in carbon sink, stored in the main tree species, have been detected between managed and unmanaged forests (Vayreda, 2013), strongly influenced by global warming (Ciais et al., 2008) and LULC (Muñoz-Rojas et al., 2011). However, the carbon stock in living biomass reached half of the total amount stored in forests occurring in northern hemisphere (Goodale et al., 2002). Accordingly, adaptive management is implemented to mitigate the effect of global warming because it reduces competition for resources limiting forest holding capacity as carbon sink (Vayreda, 2013). Forest restoration should be addressed to accelerate the natural mechanisms of succession, using adaptive forest management, mainly in Mediterranean ecosystems in which the main objectives of management usually include environmental protection and recreation (Lloret, 2004).

The main objective of this paper is to improve scientific knowledge to develop tools to support environmental decision-making in areas with excessive 
regeneration to face new challenges coming from global change scenarios in fire prone areas. To achieve it, this research aims (a) to study the effect of silvicultural treatments by monitoring naturally regenerated areas in which different intensities of thinning were implemented and (b) to study carbon sink trends by compare carbon stored in biomass of main tree species obtained in direct sampling and those contained in available published datasets.

\section{Materials and methods}

\subsection{Study sites}

We monitored regeneration of two burnt areas, one single fire occurred near the village of Yeste in the province of Albacete, south-eastern Spain $\left(Y E S, 2^{\circ} 20^{\prime}\right.$ $\mathrm{W}, 38^{\circ} 20^{\prime} \mathrm{N}$; $1010 \mathrm{~m}$ a.s.1.) burning approximately 14000 ha in summer 1994. At the other area, two fire events burnt 500 ha in summer 1993 and 50 ha in summer 2001 near Campillo de Altobuey, in the province of Cuenca, eastern Spain (CAMP, $1^{\circ} 51^{\prime} \mathrm{W}, 39^{\circ} 40^{\prime} \mathrm{S}, 1009 \mathrm{~m}$ a.s.1.).

Averaging the values of the period 1982-2007 transferred by the Spanish National Meteorological Agency (AEMET), we found, respectively for $Y E S$ and $C A M P$, that the mean annual temperature was 15 and $12^{\circ} \mathrm{C}$ and the mean annual rainfall of 496 and $517 \mathrm{~mm}$. Rivas-Martínez's thermicity index (RivasMartínez et al., 1999) indicated for both sites a dry ombroclimate located in the upper Mesomediterranean belt. YES showed low depth of soil, sandy texture and $\mathrm{pH}$ value about 8 . CAMP showed a mean depth of about $35 \mathrm{~cm}$, sandy clay loam texture and $\mathrm{pH}$ value about 8 .

Potential natural vegetation in both areas was a sclerophyllous oak forest, Bupleuro rigidi-Querceto rotundifoliae sigmetum (Rivas-Martínez, 1982). However, at YES, vegetation was a scrubland dominated by $P$. halepensis trees in the suntrap slopes meanwhile in the shady sides was dominated by Pinus pinaster Aiton. mixed with P. halepensis trees. At CAMP, we found a mixed forest dominated by Pinus pinaster Aiton mixed with Quercus ilex L. ssp ballota (Desf.) Samp and Pinus nigra ssp. salzmannii (Dunal) Franco.

\subsection{Silvicultural treatments and allometric relationships}

High plant cover was naturally re-established a few years after wildfires at both burnt areas. After wildfires, the predominant tree species at YES was P. halepensis, regenerated from seeds enclosed in serotinous cones stored in the canopy. Spatial distribution of regenerated sapling density not homogeneous, showing no regenerated zones to other occurring 7000 to 70000 pine saplings ha ${ }^{-1}$. At $C A M P$, we found a homogeneous natural regeneration with high resprouting density of $Q$. ilex (about 12000 standards $\mathrm{ha}^{-1}$ ). 
In the Aleppo pine forests at $Y E S$, we set thirty-three experimental rectangular plots $\left(10 \times 15 \mathrm{~m} ; 150 \mathrm{~m}^{2}\right)$ and carried out early silvicultural treatments in late 2004 (Moya et al., 2008). We tested three thinning intensities (null, medium and high) to assess the optimal thinning regime, implementing intensities of thinning most commonly used by the local forest service. The intra-specific competition in a mature Aleppo pine forest was simulated by carrying out a medium intensity of thinning (YES MT, final density to 1600 trees ha-1) and high intensity of thinning, reducing density to half of the initial (YES HT, to 800 trees $^{-1}$ ). In addition, unthinned plots (YES UT, ranging 8200 to 9500 trees ha-1) were maintained as control and to represent no managed areas. Mastication and pruning were carried out in 1999 but negligible or negative effects (such as reduction of productivity) induced to reject their implementation.

In the Holm oak forests at $C A M P$, burned in summer 1993, we set twelve experimental rectangular plots $\left(15 \times 20 \mathrm{~m} ; 300 \mathrm{~m}^{2}\right)$ and carried out silvicultural treatments seven years after the first fire (2000). Silvicultural treatments reduced the number of standards coming from each oak stump, in an early stage, by applying a conversion by thinning on coppice. We implemented medium intensity of thinning (CAMP MT), reducing density to 3500-5000 standards ha ${ }^{-1}$ and no thinning (unthinned, CAMP UT), where initial tree density was maintained

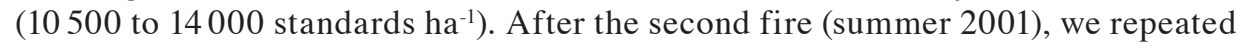
the experience setting again twelve plots and implemented thinning on coppice in early 2008 (seven years after the first fire).

In both sites, the total tree density (TD) was recorded in all plots before the treatments were carried out. After thinning, remaining trees were marked and counted again. In winter 2010, we recorded total height $(H)$ and trunk diameter $30 \mathrm{~cm}$ above soil to avoid basal defect measurements and overestimations (D30) in each tree using a height pole and a digital calliper, respectively. De las Heras et al. (2013a) and López-Serrano et al. (2010) developed allometric relationships which were revised to obtain above and below-ground biomass and calculate the total carbon sink stored in tree strata, including all class diameters (Table 1). We selected exponential regression $\left(\mathrm{M}=\mathrm{a} \mathrm{D} 30^{\mathrm{b}}\right)$, the most frequently reported in forest science (Ter-Mikaelian and Korzukhin, 1997). The allometric relationships related $D 30$ and biomass, including total $\left(B_{\text {TотАL }}\right)$ and partitions, biomass of roots or belowground $\left(B_{B E L O W}\right)$ aboveground divided in those located in trunk $\left(B_{\text {TRUNK }}\right)$ and crown ( $B_{C R O W N}$, including branches, leaves or needles and fruits or cones). We assumed that conversion factor of carbon stock was $0.5 \mathrm{Mg}$ per $\mathrm{Mg}$ of dry biomass (De Vries et al., 2003; Montero et al., 2005) to calculate the equivalent carbon fixed $\left(\mathrm{C}_{\text {TOTAL }}\right)$ and carbon stored in partitions: belowground $\left(\mathrm{C}_{\mathrm{BELOW}}\right)$, trunk $\left(\mathrm{C}_{\text {TRUNK }}\right)$ and crown $\left(\mathrm{C}_{\text {CROWN }}\right)$. We also calculated ratios of carbon stored in roots $\left(\%_{\text {BELOW }}\right)$, trunk $\left(\%_{\text {TRUNK }}\right)$ and crown $\left(\%_{\text {CROWN }}\right)$ to compare differences among tree partitions. 


\begin{tabular}{|c|c|c|c|c|c|c|c|}
\hline 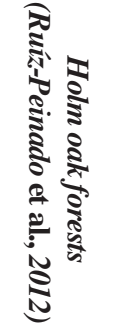 & \multicolumn{2}{|c|}{ 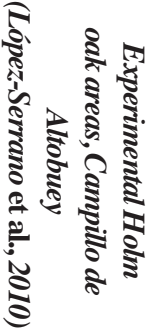 } & \multirow{2}{*}{ 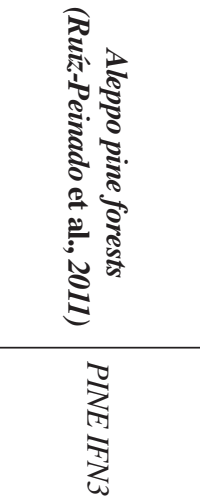 } & \multicolumn{3}{|c|}{ 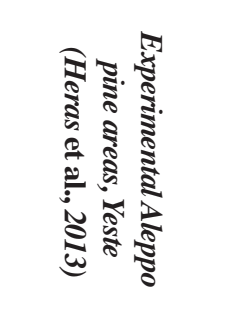 } & \multirow[b]{2}{*}{$\overbrace{0}^{2}$} \\
\hline 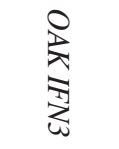 & $\underset{7}{3}$ & $\underset{\mathbb{3}}{\mathfrak{Z}}$ & & $\begin{array}{l}\mathbb{N} \\
\mathbb{N} \\
\mathbb{N}\end{array}$ & 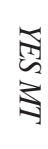 & 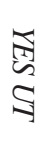 & \\
\hline 1 & 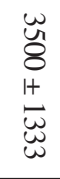 & 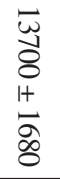 & ' & $\begin{array}{l}\infty \\
8 \\
1+ \\
\omega \\
\omega\end{array}$ & $\begin{array}{l}\overline{8} \\
8 \\
1+ \\
\overline{8}\end{array}$ & 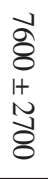 & 㲵 \\
\hline ZZ & 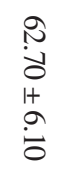 & $\begin{array}{l}0 \\
1+ \\
0\end{array}$ & Z & 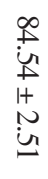 & $\begin{array}{l}2 \\
0 \\
\omega \\
\omega \\
1+ \\
N \\
\pm \\
\pm\end{array}$ & $\begin{array}{l}0 \\
1+ \\
0\end{array}$ & 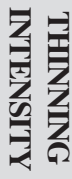 \\
\hline Z & $\checkmark$ & I & Z & $\bar{o}$ & $\sigma$ & 1 & 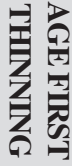 \\
\hline 1 & 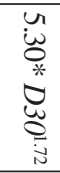 & 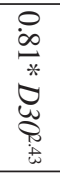 & 1 & 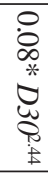 & 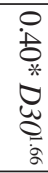 & 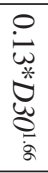 & 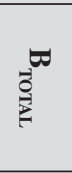 \\
\hline $\begin{array}{l}\stackrel{0}{ \pm} \\
\stackrel{f}{*} \\
\overbrace{T}^{*}\end{array}$ & 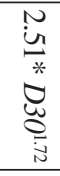 & 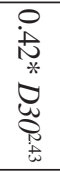 & 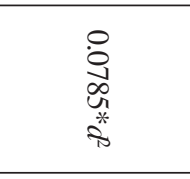 & 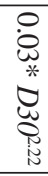 & 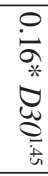 & 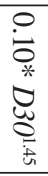 & 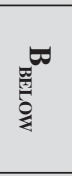 \\
\hline $\begin{array}{l}0 \\
\text { Un } \\
\text { * } \\
\text { i }\end{array}$ & 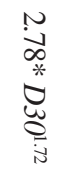 & 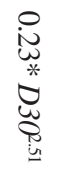 & 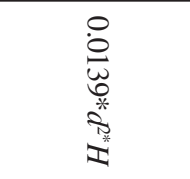 & 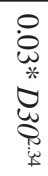 & 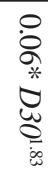 & 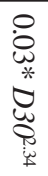 & 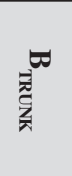 \\
\hline 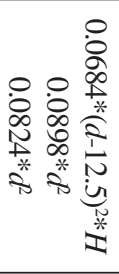 & 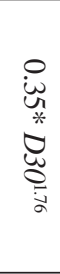 & 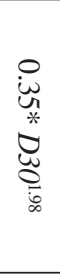 & 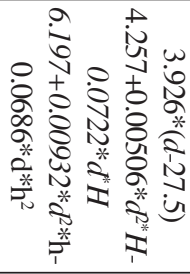 & 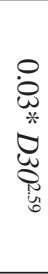 & $\begin{array}{l}\stackrel{0}{\sigma} \\
\stackrel{*}{*} \\
\stackrel{\mathscr{U}}{0} \\
\stackrel{\infty}{\infty}\end{array}$ & 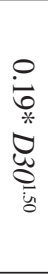 & $\begin{array}{l}\tilde{\sigma} \\
\tilde{\tilde{\tilde{N}}} \\
\tilde{z} \\
\Sigma\end{array}$ \\
\hline
\end{tabular}

क्रे

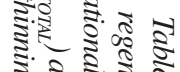

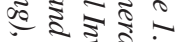

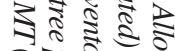
₹ฐ. ई. ‡: ₹ ร.

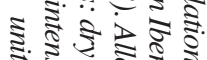
ใ. ร ร.

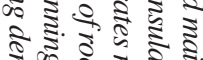

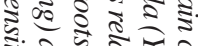

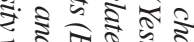

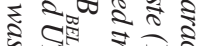
है

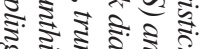
독 총 ई ई ई ई 곤제

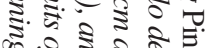

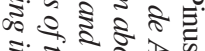

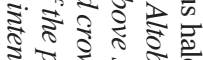
ร. ॠ

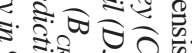
वी

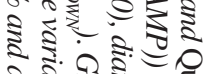

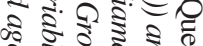
0 क है के द्व

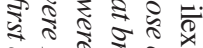
论

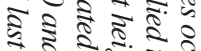
इ का

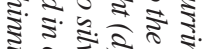

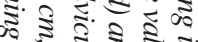

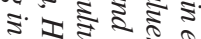

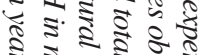

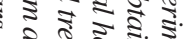

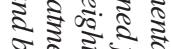
‥ จ

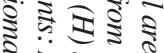

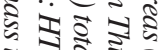

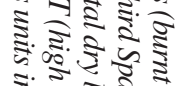

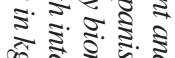

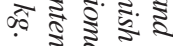
곯. 


\subsection{Carbon storage from georeferenced datasets}

Large wildlandfires and forest carbon stockswere mapped and digitized using geographical information system tools (GvSIG Development Team, 2013; Quantum GIS Development Team, 2012). Mainly, we used three official public databases provided by national and regional mapping agencies: images from the Spanish National Plan of Aerial Orthophotography (PNOA) provided by Centro Cartográfico Castilla-La Mancha, georeferenced information from Corine Land Cover (CLC) provided by Centro Nacional Información Geográfica (CNIG)) and data from Third Spanish National Forest Inventory (IFN3) provided by the Spanish Ministry of Agriculture, Food and Environment.

By using CLC database, we selected large wildlandfires (> 500 ha), including the previously described burnt and regenerated monitored areas (Fig. 1). Relating the selected surfaces to IFN3, we obtained forested areas, being $P$. halepensis the main tree species in $Y E S$ and $Q$. ilex in $C A M P$ (Fig. 2). Perimeters of the polygons representing the selected large wildlandfires and forest stands according to main tree species were corrected by using PNOA images. Subsequently, explanatory variables of our experimental plots from the clip of the study surface and the IFN3 datasets, i.e., total height $(H)$, diameter at breast height $(d)$ and tree density $(T D)$ were obtained.

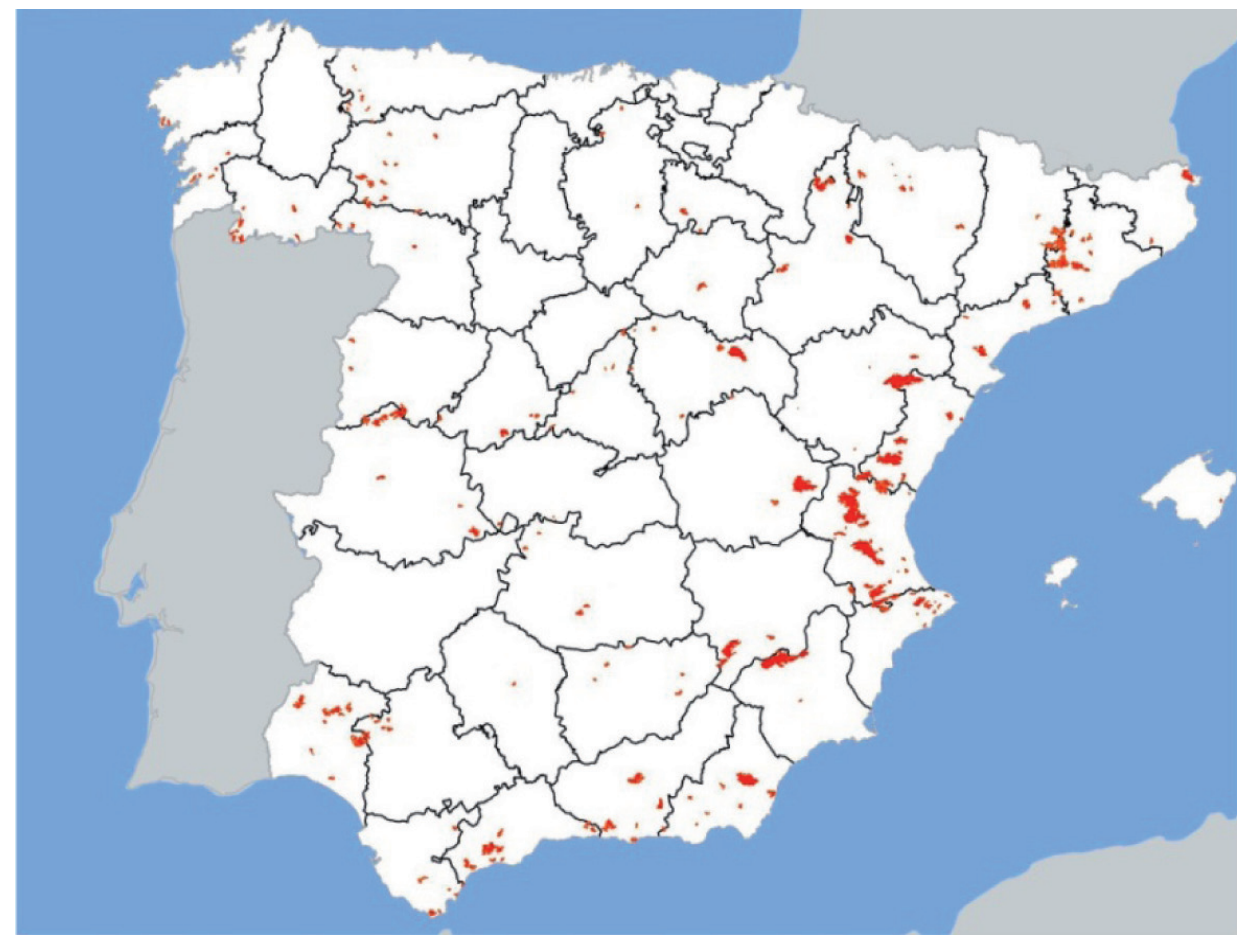

Figure 1. Large wildfires (>500 ha, in red) occurred in Spain between 1990 to 2006, information provided by the Corine Land Cover project. 


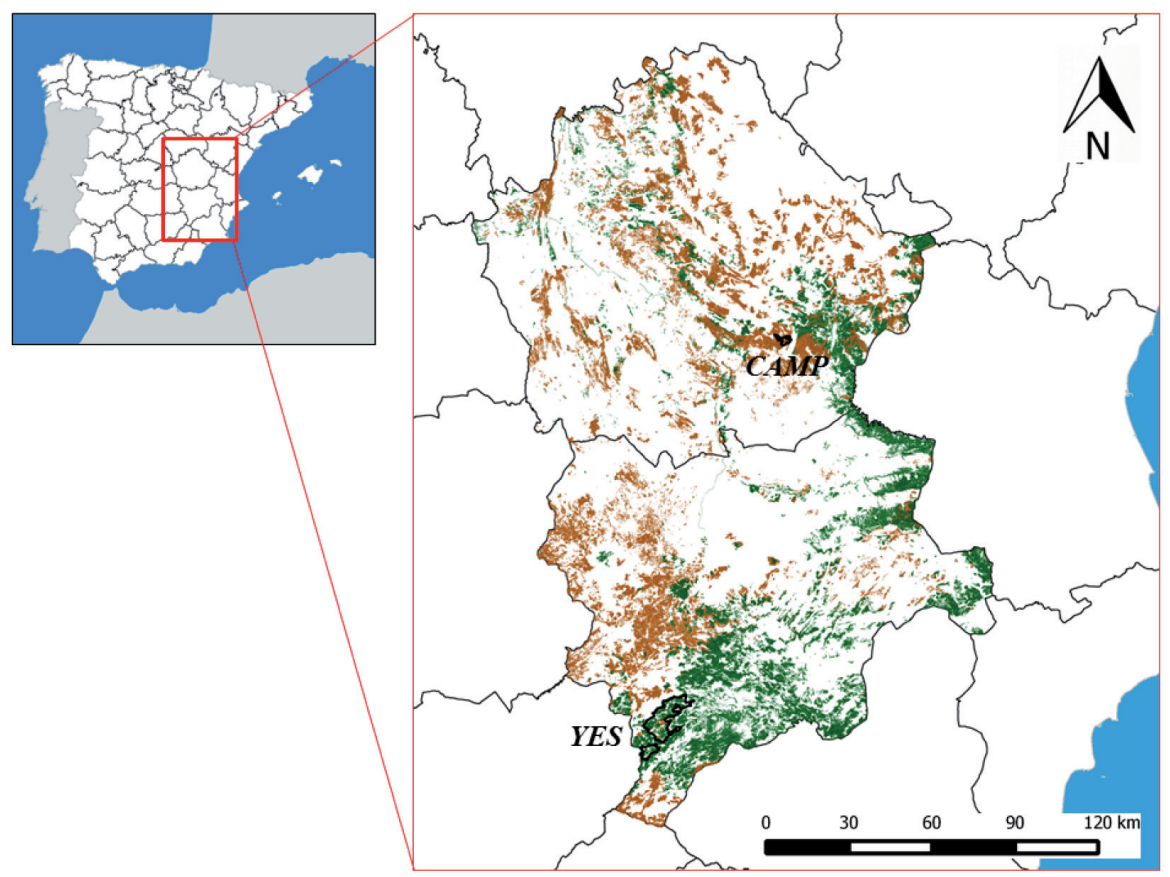

Figure 2. Two monitored large wildfires occurred in eastern Iberian Peninsula (in black, YES and CAMP). In Cuenca province, we selected two wildfires which burnt 500 ha in 1993 and 50 ha in 2001 of Quercus ilex stands (CAMP). In Albacete province, we selected a large wildfire burning almost 14000 ha (in 1994) of Pinus halepensis stands (YES). Polygons obtained from third Spanish National Forest Inventory showed Aleppo pine forests (green) and Holm oak forests (brown).

To calculate carbon stocks of mature stands, we used general allometric relationships (Ruiz-Peinado et al., 2011, 2012) relating diameter at breast height $(d)$ and height $(H)$ to biomass partitions $\left(B_{B E L O W}, B_{\text {TRUNK }}\right.$ and $\left.B_{C R O W N}\right)$, what allowed calculation of $B_{\text {TOTAL. }}$ Similarly to the previous section, we assumed a conversion factor of carbon content $(0.5$ $\mathrm{Mg}$ per Mg of dry biomass) to calculate the equivalent carbon fixed.

\subsection{Data analysis}

The predictive variables and factors were log transformed to achieve normality assumptions and homoscedasticity. However, they were shown with no transformation, including standard error (SE). The recorded and calculated data were subjected to single one-way ANOVA to test significant differences comparing different silvicultural treatments. We used Fisher's LSD test (Least Significant Difference) to check significant differences between groups, maintaining alpha level and preserving the comparison of family-wise type I error. All statistical analyses were conducted using a critical p-value of 0.05 and run under Statgraphics Plus 5.1 software. 


\section{Results}

\subsection{Carbon storage in the experimental and managed plots under regeneration}

The results showed a higher amount of carbon stored in stands occurring in YES stands $\left(6.92 \pm 1.53 \mathrm{Mg}\right.$ of $\left.\mathrm{C} \mathrm{ha}^{-1}\right)$ than in $C A M P\left(2.59 \pm 0.21 \mathrm{Mg}\right.$ of $\left.\mathrm{C} \mathrm{ha}^{-1}\right)$. In addition, significant differences were attained between different silvicultural treatments. In particular, high intensity of thinning promoted a reduction of carbon sink in the short term but an increase in the medium-long term. Table 2 shows carbon pools of silvicultural treatments for each site separately. At CAMP, we found that thinned plots showed lower $\mathrm{C}_{\text {TOTAL }}$ than CAMP UT plots. The highest total amount of carbon stored was in YES HT. However, YES MT showed lower values of $\mathrm{C}_{\mathrm{TOTAL}}$ than YES UT plots. The significant differences for tree partitions of carbon stored aboveground (trunk and crown) were similar to described for the total amount of carbon. Applying those values found to the regenerated area, we found a total amount of carbon stored in YES, ranging between 73124 to $130501 \mathrm{Mg}$ implementing HT, 30951 to 33485 implementing $M T$ and 39368 to $56563 \mathrm{Mg}$ with no management. Similarly for CAMP, we obtained 1144 to $1309 \mathrm{Mg}$ in MT stands and 1716 to $1936 \mathrm{Mg}$ in UT stands.

Table 2. Total amount of carbon stored and allocation $\left(\mathrm{Mg} \mathrm{ha}^{-1}\right)$ and percentages found in 2010 in naturally regenerated Aleppo pine forests in Yeste (YES), after a wildfire occurring in 1994, and Holm oak forests in Campillo Altobuey, after a wildfire occurring in 2001. For carbon allocation indices $\left(C_{\text {TOTAL }}\right.$ : total amount of carbon stored in trees; $C_{B E L O W}$ : carbon stored in roots of trees; $C_{\text {TRUNK }}$ : carbon stored in stems of trees; $C_{\text {CROWN }}$ : carbon stored in canopy of trees) superscripts and asterisks pointed significant differences $(p<0.05)$. For percentages $\left(\%_{\text {ROOT: }}\right.$ : percentage of total amount of carbon per tree stored in roots; $\%_{\text {STEM }}$ : percentage of total amount

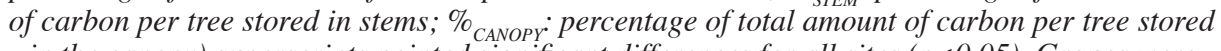
in the canopy) superscripts pointed significant differences for all sites $(p<0.05)$. Groups were related to silvicultural treatments carried out in both sites (YES and CAMP): HT (high intensity of thinning), MT (medium intensity of thinning) and UT (unthinned).

\begin{tabular}{|c|c|c|c|c|c|c|c|}
\hline \multirow{2}{*}{ KEY } & $\mathbf{C}_{\text {TOTAL }}$ & $\mathbf{C}_{\text {BELOW }}$ & $\mathbf{C}_{\text {TRUNK }}$ & $\mathbf{C}_{\text {CROWN }}$ & $\%_{\text {ROOT }}$ & \% $_{\text {STEM }}$ & $\%_{\text {CANOPY }}$ \\
\hline \multirow{2}{*}{ YES HT } & $11.25 \pm$ & $1.61 \pm$ & $2.76 \pm$ & $7.92 \pm$ & $20.85 \pm$ & $23.36 \pm$ & $55.79 \pm$ \\
& $3.17^{\mathrm{b}}$ & $0.43^{\mathrm{b}}$ & $0.72^{\mathrm{b}}$ & $2.55^{\mathrm{b}}$ & $6.19^{\mathrm{a}}$ & $7.79^{\mathrm{a}}$ & $10.31^{\mathrm{c}}$ \\
\hline \multirow{2}{*}{$\boldsymbol{Y} \boldsymbol{E S} \boldsymbol{M T}$} & $3.56 \pm$ & $0.58 \pm$ & $1.10 \pm$ & $1.68 \pm$ & $16.43 \pm$ & $36.31 \pm$ & 47.26 \\
& $0.14^{\mathrm{a}}$ & $0.02^{\mathrm{a}}$ & $0.05^{\mathrm{a}}$ & $0.07^{\mathrm{a}}$ & $0.09^{\mathrm{a}}$ & $0.10^{\mathrm{b}}$ & $\pm 0.18^{\mathrm{bc}}$ \\
\hline \multirow{2}{*}{ YES UT } & $5.30 \pm$ & $1.76 \pm$ & $1.06 \pm$ & $1.72 \pm$ & $33.52 \pm$ & $33.82 \pm$ & $32.66 \pm$ \\
& $0.95^{\mathrm{ab}}$ & $0.23^{\mathrm{b}}$ & $0.17^{\mathrm{a}}$ & $0.28^{\mathrm{a}}$ & $0.70^{\mathrm{b}}$ & $1.22^{\mathrm{b}}$ & $4.82^{\mathrm{b}}$ \\
\hline \multirow{2}{*}{$\boldsymbol{C A M P M T}$} & $2.23 \pm$ & $1.09 \pm$ & $0.79 \pm$ & $0.19 \pm$ & $49.65 \pm$ & $41.81 \pm$ & $8.54 \pm$ \\
& $0.15^{*}$ & $0.04^{*}$ & $0.03^{*}$ & $0.01^{*}$ & $1.94^{\mathrm{c}}$ & $2.30^{\mathrm{c}}$ & $0.36^{\mathrm{a}}$ \\
\hline \multirow{2}{*}{ CAMP UT } & $3.32 \pm$ & $1.57 \pm$ & $1.74 \pm$ & $0.54 \pm$ & $47.36 \pm$ & $36.35 \pm$ & $16.30 \pm$ \\
& $0.20^{* *}$ & $0.01^{* *}$ & $0.01^{* *}$ & $0.01^{* *}$ & $0.07^{\mathrm{bc}}$ & $0.10^{\mathrm{b}}$ & $0.03^{\mathrm{ab}}$ \\
\hline
\end{tabular}

The highest averaged percentage of amount of carbon stored belowground was found at $C A M P$, concretely CAMP MT. YES UT showed significant higher amount of carbon stored in roots than thinned plots. However, the carbon stored in the crown was higher in YES than CAMP stands, being higher in thinned plots than in YES UT. The percentage of the partition stored in stem showed a no clear pattern but, in general, was higher in managed plots. 


\subsection{Carbon sinks according to Spanish National Forest Inventory}

By applying the allometric relationships from literature (Table 1), we obtained total biomass for individuals and permanent plots from the Third Spanish National Forest Inventory (Fig. 3) including values from all trees included in the available plots. The values were averaged according our permanent plots. Then, we calculated the total amount of carbon stored for both studied areas (Fig. 4), comparing differences from the values showed in the previous section.
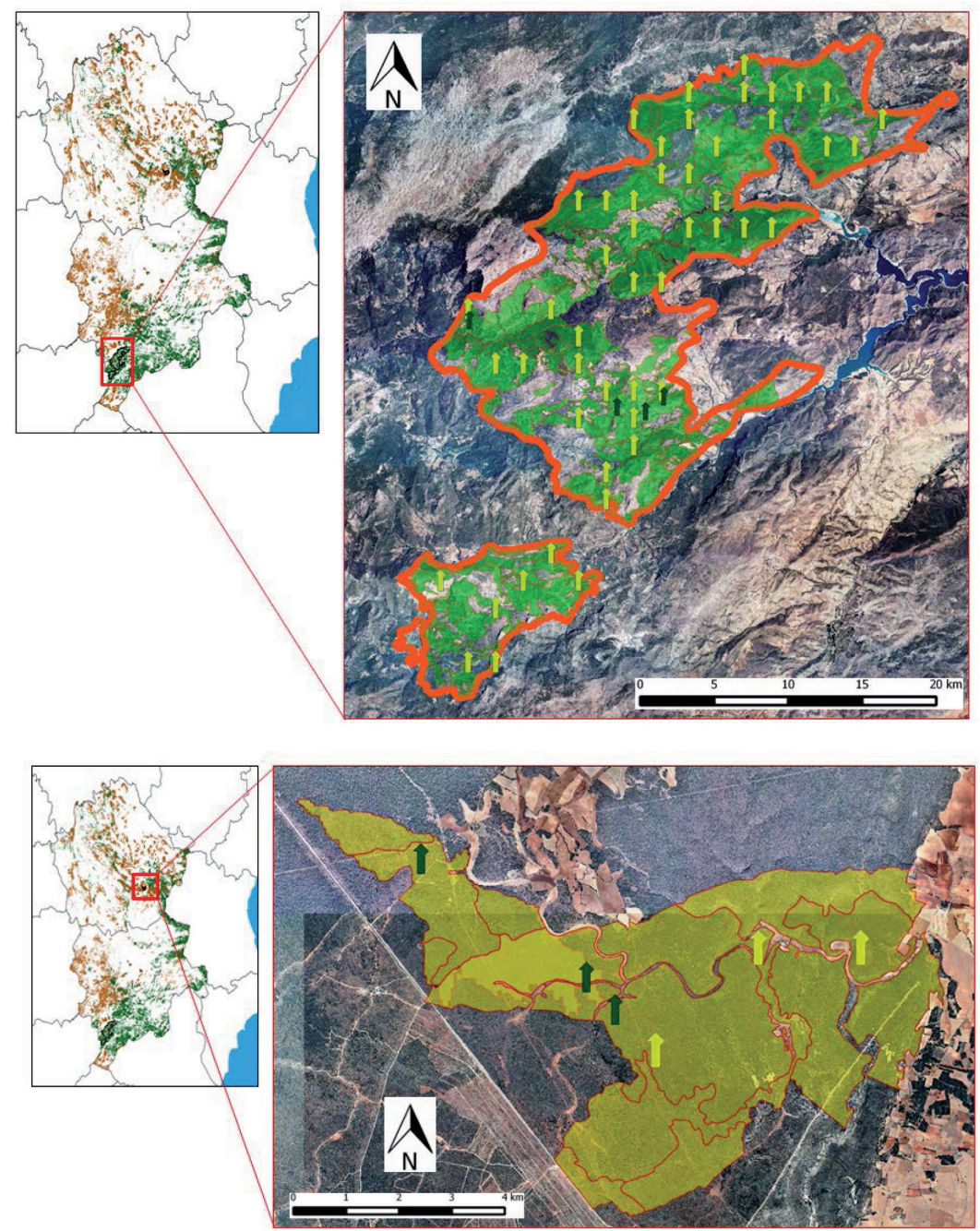

Figure 3. Two monitored wildfires occurred in eastern Iberian Peninsula. The upper image shows wildfires close to Campillo de Altobuey (eastern Cuenca province) and the lower image a wildfire occurred close to Yeste (southern Albacete province). Plots from the Third Spanish Forest Inventory (light green arrows) and experimental plots including silvicultural treatments (dark green arrows). 


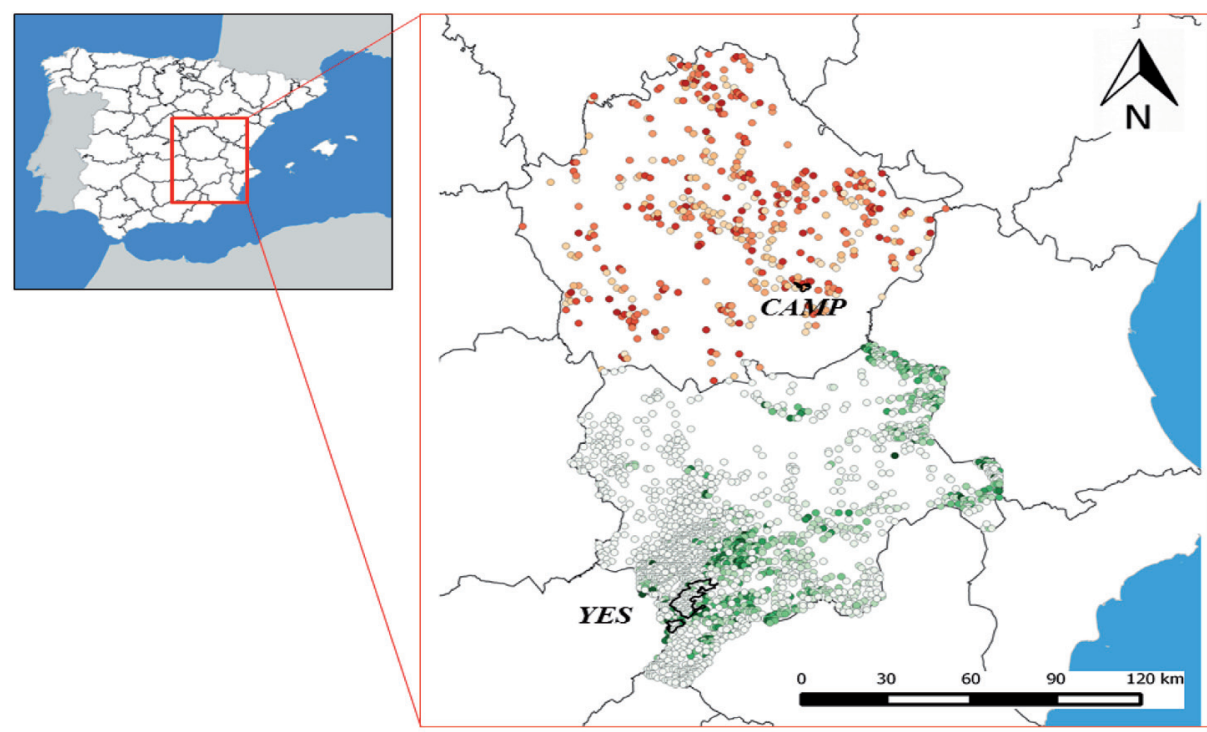

Figure 4. Carbon stock in main tree species $\left(\mathrm{Mg} \mathrm{ha}^{-1}\right)$ in the study areas (Yeste (YES) and

Campillo de Altobuey (CAMP)). Two monitored large wildfires occurred in eastern Iberian Peninsula (perimeters in black). Plots obtained from Third Spanish National Forest Inventory showed the total amount of carbon $\left(\mathrm{Mg} \mathrm{ha}^{-1}\right)$ stored in Aleppo pine forests (green) and Holm oak forests (brown). Darker color indicated higher value of carbon stocks.

For P. halepensis in plots located in Albacete province, we found averaged values of total carbon stored ranging from 0.10 to $11.84 \mathrm{Mg} \mathrm{C}^{-1}$. A large amount of plots (about 76\%) showed values lower than $1 \mathrm{Mg} \mathrm{C}^{-1}$ mainly in those occurring low tree densities. The plots showing $\mathrm{C}$ stocks higher than $5 \mathrm{Mg} \mathrm{C}^{-1}$ were located in eastern areas of the province and southern areas. Plots found in the perimeter of the monitored burnt area ranged from 1.02 to $3.22 \mathrm{Mg} \mathrm{C}^{-1}$.

For $Q$. ilex in plots located in Cuenca province, we found averaged values of total carbon stored going from 0.21 to $14.86 \mathrm{Mg} \mathrm{C} \mathrm{ha}^{-1}$. A large amount of plots showed values lower than $1 \mathrm{Mg} \mathrm{C}^{-1}$ (more than 90\%) due to the low tree density. The plots showing amounts higher than $5 \mathrm{Mg} \mathrm{Cha}^{-1}$ were located in northeaster areas. The plots found in the perimeter of the monitored burnt area ranged from 0 to $0.91 \mathrm{Mg} \mathrm{C} \mathrm{ha}^{-1}$.

\section{Discussion}

Our research linked results to previous studies about thinning effects on two widespread species occurring in the Mediterranean Basin, Aleppo pine and Holm oak, regarding to post-fire management, fire prevention and adaptive forest management (López-Serrano et al., 2006, 2010; Moya et al., 2011). Early thinning (focused to remain an adequate final tree density) had been proved to improve growth and resilience due to reduction of competition and the increase in water, light and nutrient availability (De las Heras et al., 2013a; López-Serrano et al., 2010). 
We found different results depending on species but related to the age of the stand. In the short term after thinning, Holm oak was showing lower values of carbon stored in thinned areas but is important to notice that were almost recovered in just two years after thinning. In addition, the resprouting condition of $Q$. ilex, provided a larger amount of carbon stored by the roots fraction (Table 2) (López-Serrano et al., 2010). In the Aleppo pines stand, the positive effect of high intensity of thinning was clear in individuals regenerated fifteen years ago. For both Mediterranean species, thinning was reducing the total amount of carbon stored in the short-term, but increased growth stimulation and productivity which implied higher carbon storage increase in a low number of trees (López-Serrano et al., 2010; Moya et al., 2008). The high intensity of thinning carried out in Aleppo pine stands showed benefits linked to carbon storage in the medium-term and stands thinned at medium intensity reached similar amount than unthinned areas which influenced the future development of the early thinned stands (Horner et al., 2010).

The total carbon stock in $P$. halepensis from IFN3 was similar to those plots showing higher tree density (unthinned and low intensity of thinning). However, values found for Holm oak were lower than those found in experimental plots. Differences could be explained by the fact that IFN3 was not including individual trees showing trunk diameter lower than $7,5 \mathrm{~cm}$ which could introduce a coarse error in the carbon storage valuations. However, not only trees with low diameter are neglected, companion species should also be included to obtain the total amount of carbon (Alfaro-Sánchez et al., 2013). According to Vayreda (2013), the total stock of $\mathrm{CO}_{2}$ in forests of Castilla-La Mancha was $19710^{6} \mathrm{Mg}$ and according to Bravo et al. (2007), the amount of $\mathrm{CO}_{2}$ stored in Aleppo pine forest in Cordillera Prebética was $6.9710^{6} \mathrm{Mg}$ and stored in Holm oak in Sistema Ibérico Meridional was $10.2910^{6} \mathrm{Mg}$.

For forests located in South-eastern Spain, mainly those showing low site quality, the optimal management should aim to diverse objectives, including conservation, biodiversity, resilience, restoration, fire prevention or carbon sequestration (Montero et al., 2001). The total carbon pool stored in national forest carbon estimations should include biomass storage in young stands regenerated after fire, advising the early management of areas showing excessive regeneration to implement adaptive management, but depending on the site quality (Alfaro-Sánchez et al., 2013).

\section{Conclusions}

Adaptive management facing land use and land cover changes in addition to climate change, should take into account the development of basic scientific knowledge of classic tools to include them. For Holm oak stands, no significant effects in biomass increase were found, however, the monitoring of these areas should be maintained to obtain results in the medium and long term. The high intensity of thinning (decreasing the final tree density to 800 tree $^{-1}$ ) was optimal to improve the amount of carbon stock in those Aleppo pine stands showing excessive regeneration after wildfires. Carbon stocks in national forest inventories and similar tools should include young stands, mainly those naturally regenerated in burnt areas. However, tools, formulas and allometric relationships had to be improved and developed to be properly used in growth models. 
In order to help to managers and stakeholders in the decision making, mainly in low timber productive Mediterranean areas to estimate biomass and carbon stock as an extra income, we advise to develop tools for different areas and ages, depending on site quality and including class diameters and main companion species. It should be developed by direct sampling and validation of new technologies to extrapolate results to greater areas, such as remote sensing, geographic information systems and Lidar information.

\section{Acknowledgments}

We thank Spanish Ministry for Economy and Competitiveness for providing funding and support to the Forest Ecology Researching Group in the projects AGL2008-03602/ FOR, AGL2011-27747 and CONSOLIDER-INGENIO 2010: MONTES (CSD 200800040). We would also like to thank the Consejería de Educación y Ciencia de la Junta de Comunidades de Castilla-La Mancha for their support in the Regional projects PCC 08-0109 (ECOFLUX II) and POII 09-0096-3367. Two anonymous reviewers contributed with their constructive comments to improve the manuscript.

\section{References}

Alfaro-Sánchez, R., López-Serrano, F.R., Rubio, E., De las Heras, J., Moya, D. 2013. La importancia del sotobosque en la cuantificación de los depósitos de carbono en masas jóvenes de Pinus halepensis Mill. en el SE español. Actas Del VI Congreso Forestal Español, Vitoria.

Barron-Gafford, G.A., Will, R.E., Burkes, E.C., Shiver, B., Teskey, R.O. 2003. Nutrient concentrations and contents, and their relation to stem growth, of intensively managed Pinus taeda and Pinus elliottii stands of different planting densities. Forest Science 49 (2), 291-300.

Bravo, F. 2007. El papel de los bosques españoles en la mitigación del cambio climático. Fundación Gas Natural, Barcelona.

Castro, J., Allen, C.D., Molina-Morales, M., Marañón-Jiménez, S., Sánchez-Miranda, A., Zamora, R. 2011. Salvage logging versus the use of burnt wood as a nurse object to promote post-fire tree seedling establishment. Restoration Ecology 19 (4), 537-544.

Ciais, P., Schelhaas, M., Zaehle, S., Piao, S., Cescatti, A., Liski, J. 2008. Carbon accumulation in European forests. Nature Geoscience 1 (7), 425-429.

Christensen, N., Bartuska, A., Brown, J., Carpenter, S., D’Antonio, C., Francis, R., Franklin, J., MacMahon, J., Noss, R., Parsons, D., Peterson, C., Turner, M., Woodmansee, R. 1996. The report of the Ecological Society of America committee on the scientific basis for ecosystem management. Ecological Applications 6, 665-691.

De las Heras, J., Moya, D., Vega, J.A., Daskalakou, E., Vallejo, R., Grigoriadis, N., Tsitsoni, T., Baeza, J., Valdecantos, A., Fernández, C., Espelta, J., Fernandes, P. 2012. Post-Fire Management of Serotinous Pine Forests. In Post-Fire Management and Restoration of Southern European Forests, F. Moreira, M. Arianotsou, P. Corona, J. de las Heras (eds.), Managing Forest Ecosystems 24, 151-170.

De las Heras, J., Moya, D., López-Serrano, F.R., Rubio, E. 2013a. Carbon sequestration of naturally regenerated Aleppo pine stands in response to early thinning. New Forests 44 (3), 457-470.

De las Heras, J., Moya, D., Lloret, F., Vallejo, V.R., Castro, J., López-Serrano, F.R., Retana, J., Espelta, J.M. Rodrigo, A. 2013b. Incendios forestales. In Conservar Aprovechando. Cómo integrar el cambio global en la gestión de los montes españoles, E. Doblas-Miranda (ed.), Ministerio de Economía y Competividad, Madrid, pp. 45-53. 
De Vries, W., Reinds, G.J., Posch, M., Sanz, M.J., Krause, G.H.M., Calatayud, V., Renaud, J.P. 2003. Intensive Monitoring of Forest Ecosystems in Europe, 2003 Technical report. European Commission, Brussels, and United Nations Economic Commission for Europe, Geneva.

González-Ochoa, A., De las Heras, J. 2002. Effects of post-fire silviculture practices on Pachyrhinus squamosus defoliation levels and growth of Pinus halepensis Mill. Forest Ecology and Management 167 (1-3), 185-194.

Goodale, C., Apps, M., Birdsey, R., Field, C., Heath, L., Houghton, R., Jenkins, J., Kohlmaier, G., Kurz, W., Liu, S., Nabuurs, G.J., Nilsson, S., Shvidenko, A. 2002. Forest carbon sinks in the northern hemisphere. Ecological Applications 12, 891-899.

GvSIG Development Team. 2013. GvSIG desktop (version 1.12).

Horner, G.J., Baker, P.J., MacNally, R., Cunningham, S.C., Thompson, J.R., Hamilton, F. 2010. Forest structure, habitat and carbon benefits from thinning floodplain forests: managing early stand density makes a difference. Forest Ecology and Management 259, 286-293.

Lloret, F. 2004. Régimen de incendios y regeneración. In Ecología del bosque mediterráneo en un mundo cambiante, F. Valladares (ed.), Ministerio de Medio Ambiente. Organismo Autónomo de Parques Nacionales, Madrid.

Lombardero, M.J., Ayres, M.P. 2011. Factors influencing bark beetle outbreaks after forest fires on the Iberian Peninsula. Environmental entomology 40(5), 1007-1018.

López-Serrano, F.R., De las Heras, J., González-Ochoa, A.I., García-Morote, F.A., Landete, T., Andrés, M., Moya, D., Del Cerro, A. 2006. Quercus ilex L. and Pinus halepensis Mill. post fire forest stands improve growth after thinning treatments as a consequence of a better availability of N. In New Developments in Ecology Research, A.R. Burke (ed.), Nova Science Publisher, Inc. New York, pp. 99-139.

López-Serrano, F.R., De Las Heras, J., Moya, D., García-Morote, F.A., Rubio, E. 2010. Is the net primary productivity of coppice forest stands of Quercus ilex ssp. ballota affected by post-fire thinning treatments and recurrent fires? International Journal of Wildland Fire 19, 637-648.

Martínez-Sánchez, J.J., Ferrandis, P., De las Heras, J., Herranz, J.M. 1999. Effect of burnt wood removal on the natural regeneration of Pinushalepensis after fire in a pine forest in Tus valley (SE Spain). Forest Ecology and Management 123, 1-10.

Mazza, R. 2007. Managing forests after fire. Science Update 15. U.S. Department of Agriculture, Forest Service, Pacific Northwest Research Station. Portland, OR, 12 pp.

Montero, G., Cañellas, I., Ruiz-Peinado, R. 2001. Growth and yield models for Pinus halepensis Mill. Forest Systems 20 (1), 179-201.

Montero, G., Ruiz-Peinado, R., Muñoz, M. 2005. Producción de biomasa y fijación de $\mathrm{CO}_{2}$ por los bosques españoles. Monografías INIA: Serie Forestal 13, Madrid.

Moreira, F., Arianoutsou, M., Vallejo, R.V., De las Heras, J., Corona, P., Xanthopoulos, G., Fernandes, P., Papageorgiou, K. 2012. Setting the scene for post-fire management. In PostFire Management and Restoration of Southern European Forests, F. Moreira, M. Arianotsou, P. Corona, J. de las Heras (eds.), Managing Forest Ecosystems 24, 1-19.

Moreno, M.V., Chuvieco, E. 2013. Characterising fire regimes in Spain from fire statistics. International Journal of Wildland Fire 22(3), 296-305.

Moya, D., De las Heras, J., López-Serrano, F.R., Leone, V. 2008. Optimal intensity and age of management in young Aleppo pine stands for post-fire resilience. Forest Ecology and Management 255, 3270-3280.

Moya, D., De las Heras, J., Ferrandis, P., Herranz, J.M., Martínez-Sánchez, J.J. 2011. Fire resilience and forest restoration in Mediterranean fire-prone areas. Technology and Knowledge Transfer e-Bulletin 2 (3). 
Moya, D., Ferrandis, P., De las Heras, J. 2013. Efectos del fuego sobre las comunidades vegetales. Red Temática Nacional Efectos de los Incendios Forestales sobre los Suelos (FUEGORED). Ficha técnica FGR2013/06.

Muñoz-Rojas, M., De la Rosa, D., Zavala, L.M., Jordán, A., Anaya-Romero, M. 2011. Changes in land cover and vegetation carbon stocks in Andalusia, Southern Spain (1956-2007). Science of the Total Environment 40 (14), 2796-2806.

Oliet, J.A., Planelles, R., Artero, F., Valverde, R., Jacobs, D.F., Segura, M.L. 2009. Field performance of Pinus halepensis planted in Mediterranean arid conditions: relative influence of seedling morphology and mineral nutrition. New Forests 37, 313-331.

Pausas, J. 2006. Simulating Mediterranean landscape pattern and vegetation dynamics under different fire regimes. Plant Ecology 187, 249-259.

Pausas, J.G., Fernández-Muñoz, S. 2012. Fire regime changes in the Western Mediterranean Basin: from fuel-limited to drought-driven fire regime. Climatic Change 110, 215-226.

Pausas, J.G., Paula, S. 2012. Fuel shapes the fire-climate relationship: evidence from Mediterranean ecosystems. Global Ecology and Biogeography 21, 1074-1082.

Quantum GIS Development Team. 2012. Quantum GIS Geographic Information System (version 1.08). Open Source Geospatial Foundation Project.

Quezel, P. 2000. Taxonomy and biogeography of Mediterranean pines (Pinus halepensis and P. brutia). In Ecology, Biogeography and Management of Pinus halepensis and P. brutia forest ecosystems in the Mediterranean basin, G. Ne'eman, L. Trabaud (eds.), Backhuys Publishers, Leiden, pp. 1-12.

Rivas-Martínez, S. 1987. Memoria del Mapa de las Series de Vegetación de España. ICONA, Madrid.

Rivas-Martínez, S., Sánchez-Mata, D., Costa, M. 1999. North American boreal and western temperate forest vegetation. Itinera Geobotanica 12, 5-316.

Ruiz-Peinado, R., Río, M., Montero, G. 2011. New models for estimating the carbon sink capacity of Spanish softwood species. Forest Systems 20 (1), 176-188.

Ruiz-Peinado, R., Montero, G., Río, M. 2012. Biomass models to estimate carbon stocks for hardwood tree species. Forest Systems 21 (1), 42-52.

Swank, W.T., Schreuder, H.T. 1974. Comparison of three methods of estimating surface area and biomass for a forest of young eastern white pine. Forest Science 20, 91-100.

Ter-Mikaelian, M.T., Korzukhin, M.D. 1997. Biomass equations for sixty-five North American tree species. Forest Ecology and Management 97, 1-24.

Terradas, J. 1999. Holm oak and Holm oak Forests: An introduction. In Ecology of Mediterranean evergreen oak forests, F. Rodà, J. Retana, C.A. Gracia, J. Bellot (eds.), Springer-Verlag, Berlin, Ecological studies 137, pp. 3-14.

Vallejo, R., Valdecantos, A. 2008. Incendios forestales. Lucinda B2, 1-10.

Vayreda, J. 2013. Una herramienta para la estimación del balance de C a escala nacional. In Conservar Aprovechando. Cómo integrar el cambio global en la gestión de los montes españoles, E. Doblas-Miranda (ed.), Ministerio de Economía y Competividad, Madrid, pp. 89-91.

Vayreda, J., Martínez-Vilalta, J., Gracia, M., Retana, J. 2012. Recent climate changes interact with stand structure and management to determine changes in tree carbon stocks in Spanish forests. Global Change Biology 18, 1028-1041.

Vega, J.A., Fontúrbel, T., Fernández, C., Arellano, A., Díaz-Raviña, M., Carballas, T., Martín, A., González-Prieto, S., Merino A., Benito, E. 2013. Acciones urgentes contra la erosión en áreas forestales quemadas. Guía para su planificación en Galicia. Xunta Galicia, Lourizan (Pontevedra). 
Moya et al.

Zavala, M.A. 2003. Dinámica y sucesión en bosques mediterráneos: modelos teóricos e implicaciones para la silvicultura. In Restauración de Ecosistemas Mediterráneos, J.M. ReyBenayas, T. Espigares, J.M. Nicolau (eds.), Universidad de Alcalá de Henares, Alcalá de Henares.

Zavala, M.A., Zamora, R., Pulido, F., Blanco, J.A., Imbert, B., Marañón, T., Castillo, F., Valladares, F. 2004. Nuevas perspectivas en la conservación, restauración y gestión sostenible del bosque mediterráneo. In Ecología del bosque mediterráneo en un mundo cambiante, F. Valladares (ed.), Ministerio de Medio Ambiente, Organismo Autónomo de Parques Nacionales, Madrid. 